\title{
ANALYSIS OF BISMUTH SHOT BEHAVIOR DURING CASTING
}

\author{
A. . Ryabov, South Ural State University, Russian Federation, avrmetall@ya.ru
}

\begin{abstract}
The paper considers an analysis of the behavior of bismuth shot and offers technological recommendations to improve alloy process during siphon casting of steel into ingots weighing 2.8 tons. In order to increase the bismuth assimilation in steel during siphon casting, it is necessary to implement such parameters of bismuth casting and supply that bismuth evaporation and evacuation of its vapors into the atmosphere is reduced to a minimum, and the bismuth dissolution ends when a bismuth particle moves in siphon wiring channels. Linear steel casting speed in the mold up to a height of $300-400 \mathrm{~mm}$ is maintained in the range of $10-15 \mathrm{~mm} / \mathrm{s}$, and then the speed is reduced up to $5-7 \mathrm{~mm} / \mathrm{s}$ and the bismuth is input. After the end of bismuth input, the linear casting speed is increased up to $10-15$ $\mathrm{mm} / \mathrm{s}$ during $2-5$ seconds. The casting is finished with speed at a rate of $1.5-3 \mathrm{~mm} / \mathrm{s}$.

Keywords: free-machining steel; bismuth shot; analysis; steel; steel casting.
\end{abstract}

\section{Introduction}

In recent years, techniques of steel micro alloy process and modifying are developed effectively. The techniques are realized by introducing lump materials into a ladle, by injecting modifiers using an inert gas stream, by the use of cored wire, and by additive of small disperse components in steel stream during the casting. The metal processing by easily oxidized elements occurs the most successfully when the process is maximum approximated to the begin of the melt solidification. Additive of reagents may be carried out in the tundish, mold continuous casting machine or a steel stream, flowing from a steel pivot ladle at the riser during siphon casting of steel [1].

\section{Main Part}

In this paper we consider a well-known technological method used in the modern steelmaking. The method is to introduce a bismuth as a shot in the riser on the metal stream during siphon casting of steel. The study is caused by a high vapor pressure, a low bismuth solubility and a complexity of its introduction into the steel, an instability of bismuth uptake results and therefore the effect obtained by alloying.

Bismuth shots in the riser are in free fall and heat (Fig. 1). During the time interval from input of the particles in the riser to the moment, when they contact with steel, the particles can become liquid or save solid state. After contact with steel, the particles continues to heat up, dissolve and evaporate. Dissolution of bismuth in the steel is complex. First of all, liquid bismuth begins to dissolve due to contact with steel. Simultaneously, liquid bismuth evaporates. Some part of gas is evacuated into the atmosphere. Another part dissolves in two ways. First is directly in the liquid steel stream flowing out of the bucket. Second is in contact surface of metal stream with metal in the riser.

Bismuth evacuation into the atmosphere occurs both through a central upper part (a filling funnel) and through leaks in the siphon wiring. If central inner surface has a 


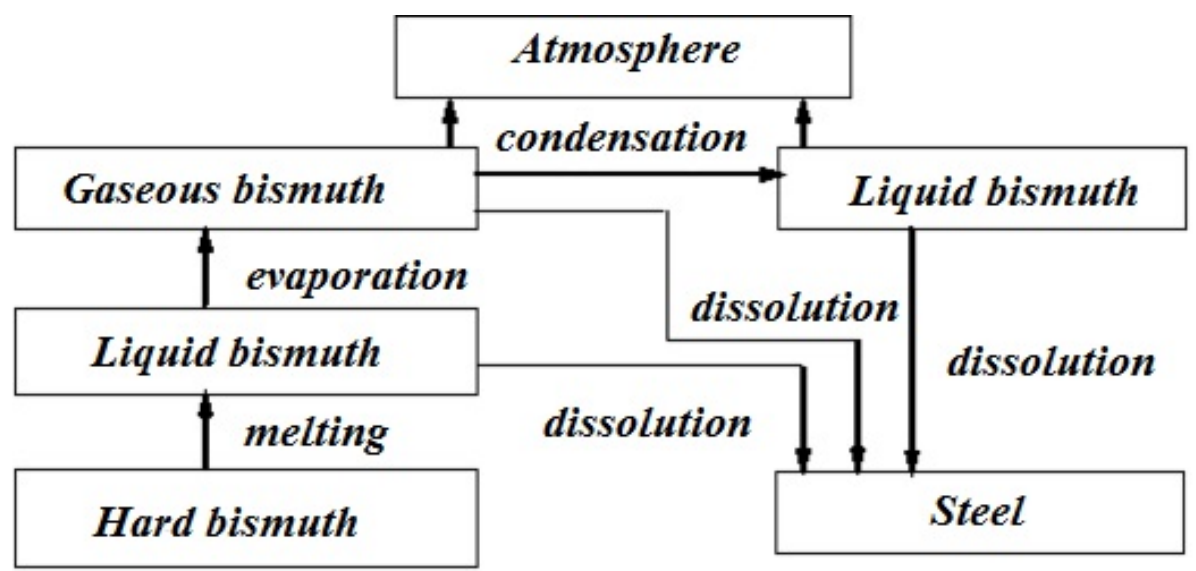

Fig. 1. Bismuth behavior in the process of alloying during the siphon casting

temperature less than the temperature of boiling bismuth $\left(1560{ }^{\circ} \mathrm{C}\right)$, then the gaseous bismuth condensates on the surface. Next, bismuth dissolves in steel during subsequent casting, then a level of steel in riser is equal to the condensate bismuth level.

Partially evaporating bismuth particle is taken by steel stream and flows with the jet on the siphon channels, where the particle dissolves in steel. This process, according to Fig. 1, can occur in two ways: $B i_{H} \rightarrow B i_{L} \rightarrow[B i]$ and $B i_{H} \rightarrow B i_{L} \rightarrow B i_{G} \rightarrow[B i]$. Apparently, both ways are realized during the alloy process.

The first way is realized in laminar steel jet, if pressure of saturated bismuth vapor is less than an external pressure. If the saturated vapor pressure is greater than an external pressure, then the second way is realized even for a laminar flow.

The second dissolution way is realized, when steel turbulent moves by siphon channels. During such movement there are some positions with the greatest turbulence, where external pressure may become less than the vapor pressure. Therefore, a vapor layer is formed around the liquid bismuth particle. Such layer may extend. Several bismuth vapor bubbles may break away, when the vapor layer extends.

The greatest vortex movement occurs in the riser, where either steel jet is connected with metal volume or steel flow sharply turns. There exist two types of turn during siphon casting. They are to transit from riser to siphon wiring and from the siphon wiring to a mould.

\section{Calculation Part}

The formation of gaseous bismuth from the liquid bismuth should be enough evenly. Otherwise, a flow speed sharply decreases and the riser becomes full of the steel. Here is an example. Let us introduce $2-5 \mathrm{~g}$ of bismuth per $1000 \mathrm{~g}$ of steel. Suppose that all bismuth becomes gaseous. A volume of introducing bismuth is $924-2400 \mathrm{~cm}^{3}$ at a temperature of $1833 \mathrm{~K}$. Note that a volume of considering steel at a density of $7 \mathrm{~g} / \mathrm{cm}^{3}$ is $143 \mathrm{~cm}^{3}$. Therefore a volume of the formed gas-metal emulsion is in 7.50 - 17.9 times more than the volume of steel.

Consider free fall of bismuth shot without contact with the steel. Suppose that radiation heating is prevalence ( "thin"body, $B i \leq 0.25$ criterion). Then the time of shot 
heating can be determined by the formula [2]:

$$
\tau=\frac{S \cdot \rho \cdot c}{k_{1} \cdot c_{e m}} \cdot \frac{100}{\left(\frac{T_{1}}{100}\right)^{3}}\left[\psi\left(\frac{T_{2}}{T_{1}}\right)-\psi\left(\frac{T_{3}}{T_{1}}\right)\right],
$$

where $c_{e m}$ is a emissivity; $k_{1}$ is a coefficient of the material load, depending on the shape of the body, $T_{1}$ is an environment temperature, where a drop heats, $K ; c$ is a specific heat; $\rho$ is a density; $S$ is a thickness of the heated layer (take equal to the radius for even two-sided heating).

Let $k_{1}=3.0$ for the ball. For $800^{\circ} \mathrm{C}$ a bismuth density is $9400 \mathrm{~kg} / \mathrm{m}^{3}$ and a specific heat of bismuth is $166.216 \mathrm{~J} / \mathrm{kg} \times{ }^{\circ} \mathrm{C}[3]$.

$$
c_{e m}=c_{0} \times \varepsilon_{e m},
$$

where $c_{0}$ is a radiation coefficient of blackbody; $\varepsilon_{e m}=\varepsilon_{1} \times \varepsilon_{2}$, where $\varepsilon_{1}, \varepsilon_{2}$ are blackness degrees of the first and second gray bodies, respectively.

Consider $F 2>>F 1$ (a stream diameter is $60 \mathrm{~mm}$, a shot diameter is $4 \mathrm{~mm}$ ) and $\varepsilon_{e m} \approx \varepsilon_{1}$, then, for bismuth, $\varepsilon_{e m}=0.381$ [4]. Assume $c_{0}=4.96 \frac{W t}{m^{2} K^{4}}$ for the gray body.

We find the free-fall time from the formula:

$$
\tau=\sqrt{\frac{2}{g}}
$$

From formulas (1) and (3), express $\psi\left(\frac{T_{2}}{T_{1}}\right)$ and define the heating temperature of a shot (Fig. 2).

Carried out shot heating evaluation shows that to reduce a temperature of the shot at the time of its contact with the steel it is necessary to increase the diameter of shots and reduce the distance flown it or shield shots during input.

To evaluate the factors affecting the process of bismuth evaporation (assimilation of bismuth by steel), we calculate the heat balance between a heat supplied to a shot and a heat expended on the evaporation [5].

By conditions of the heat balance between the supplied heat and the heat expended on bismuth evaporation, the amount of heat supplied during time $d \tau$ to the drop having radius $r$ is equal to

$$
d Q=4 \pi \cdot r^{2} \alpha\left(T_{m}-T_{s}\right) d \tau
$$

where $\alpha$ is a heat transfer coefficient; $T_{m}$ is a steel temperature; $T_{s}$ is a drop surface temperature at the time of its contact with the steel.

An amount of bismuth, which evaporates due to such heat, is

$$
d G=\frac{d Q}{Q_{B i}}
$$

where $Q_{B i}$ is a specific heat of bismuth vaporization.

Represent $d G$ as follows:

$$
d G=-4 \pi \cdot r^{2} \rho_{B i} d r
$$

where $\rho_{B i}$ is a bismuth density at boiling temperature. 


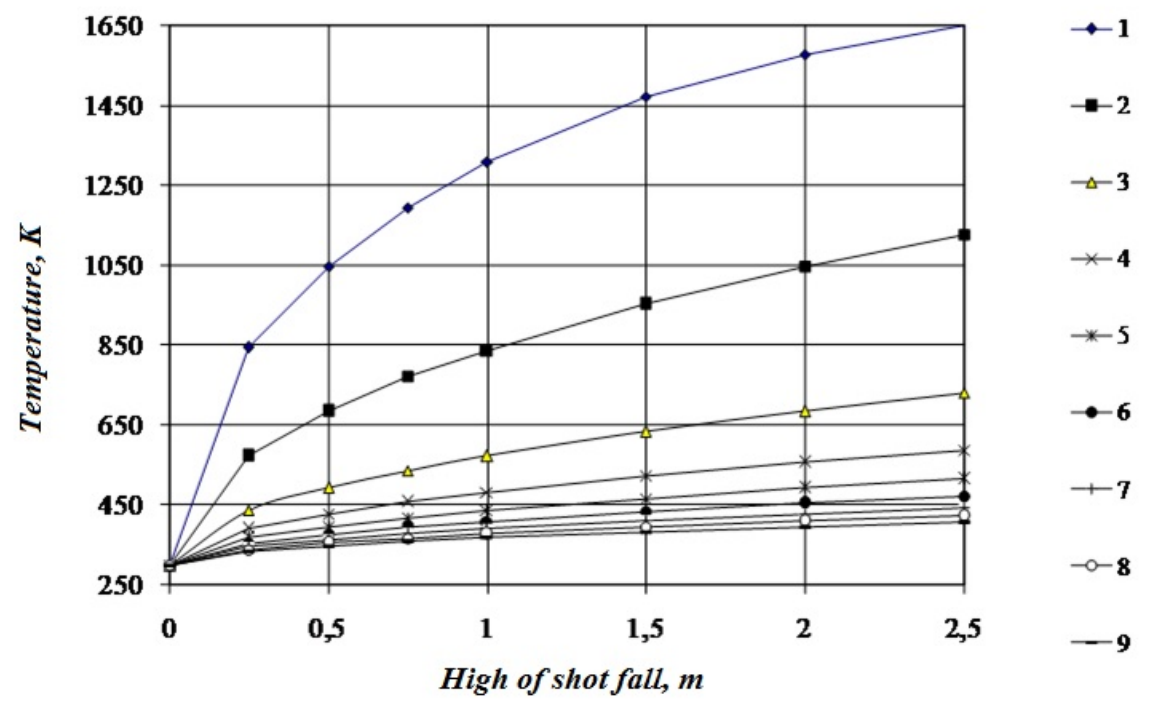

Fig. 2. A dependence of shot temperature on a height of the shot fall and its size: 1 - diameter of $0.25 \mathrm{~mm} ; 2-0.5 \mathrm{~mm} ; 3-1 \mathrm{~mm} ; 4-1.5 \mathrm{~mm} ; 5-2 \mathrm{~mm} ; 6-2.5 \mathrm{~mm} ; 7-3 \mathrm{~mm} ; 8-3.5$; $9-4 \mathrm{~mm}$

Based on the conditions of heat balance, substitute (4) and (5) in (6) and obtain:

$$
-4 \pi \cdot r^{2} \rho_{B i} d r=\frac{4 \pi \cdot r^{2} \alpha\left(T_{m}-T_{s}\right) d \tau}{Q_{B i}},
$$

therefore

$$
d \tau=\frac{\rho_{B i} Q_{B i}}{\alpha\left(T_{m}-T_{s}\right)} d r
$$

To solve equation (7) it is necessary to know the value of $\alpha$, which can be found from the conditions of heat exchange between the steel and the drop. According to O. Krisher [6] for $R e=10-10^{5}$ the formula for the heat exchange between bodies of any form is as follows:

$$
N u=0.662 \cdot \operatorname{Pr}^{1 / 3} \operatorname{Re}^{1 / 2} .
$$

Defining parameter for a ball is $l=\pi r$ (along the radius).

Criteria of Nusselt, Prandtl and Reynolds are found from the formula:

$$
\begin{gathered}
N u=\frac{\alpha \cdot l}{k}, \\
\operatorname{Pr}=\frac{\nu}{a}=\frac{\eta \cdot c}{k}, \\
R e=\frac{v \cdot l}{\nu},
\end{gathered}
$$

where $\nu$ is a kinematic viscosity; $a$ is a thermal diffusivity coefficient; $\eta$ is a dynamic viscosity; is a specific heat of the liquid; $v$ is a speed of liquid flow; $l$ is a particle size in the stream. 
Express $\alpha$ from (9) and substitute in equations (8) and (11):

$$
\alpha=\frac{0.662 \cdot \operatorname{Pr}^{1 / 3} \cdot\left(\frac{v \pi r}{\nu}\right)^{1 / 2} k}{(\pi r)^{1 / 2}}
$$

Substitute (12) in (8), integrate and obtain:

$$
\tau-\tau_{o}=-\frac{2}{3} \cdot \frac{\rho_{B i} Q_{B i} \sqrt{\pi \nu}}{0.662 \cdot \operatorname{Pr}^{1 / 3} k\left(T_{m}-T_{s}\right) \sqrt{v}}\left(r^{3 / 2}-r_{o}^{3 / 2}\right),
$$

Bismuth assimilation is found from the formula:

$$
\left(\frac{r}{r_{o}}\right)^{3}=\left(1-\frac{\Delta V}{V_{o}}\right)
$$

where $\Delta V$ is a change of drop volume; $V_{0}$ is an initial volume of the drop.

In view of equations (13), (14) and $\tau_{0}=0$ we obtain the bismuth assimilation:

$$
\left(\frac{r}{r_{o}}\right)^{3}=\left(1-\frac{0.993 \cdot \operatorname{Pr}^{1 / 3} k\left(T_{m}-T_{s}\right) \tau \sqrt{v}}{\rho_{B i} Q_{B i} r_{o}^{3 / 2} \sqrt{\pi \nu}}\right)^{2}
$$

Therefore, bismuth assimilation increases (an evaporation decreases), when a relative speed of liquid flow, a contact time of the drop and the steel stream, a temperature difference between the steel and the drop surface decrease and an initial drop size increases.

Bismuth particle is heated by contact with the metal. The particle is partially located on the metal surface, before it is taken in metal by the steel stream. Note that particle surface contacts both the gaseous medium and the metal. The particle surface, contacted with the metal, dissolves in it, and the particle surface, contacted with the gaseous medium, evaporates. The evaporation of a pure substance is generally limited by one of two successive links of the process. They are a dissociation from the surface and a mass transfer in the gas phase. For static process of evaporation, an amount of the substance evaporating from the bismuth surface and diffusing through the gas phase layer, which does not knead, are comparable [7].

Since the substance stream from a unit of evaporation surface area is, in this case, an evaporation speed $v$, then for the stationary process:

$$
v=K_{e f} \cdot c
$$

where $K_{e f}$ is an effective equilibrium constant; is a bismuth concentration in the bismuth drop. Constant

$$
\frac{1}{K_{e f}}=\frac{1}{K_{1}}+\frac{1}{K_{2}}
$$

where $K_{1}$ is a constant of evaporation act, which does not depend on the pressure $(P)$ in the gas phase; $K_{2}$ is a constant of mass flow speed of the gas, $K_{2}$ substantially depends on $P$ and a speed of the gas phase move;

$$
v=v_{1}=v_{2} ; \quad v_{1}=K_{1} \cdot C ; \quad v_{2}=K_{2}\left(C_{0}-C\right)
$$


where $C_{0}$ is a concentration of the saturated bismuth vapor; $C$ is a concentration of bismuth vapor in the environment.

For steel casting temperatures and external pressure $P=1 \mathrm{~atm}$, the limiting stage of bismuth evaporation is bismuth vapor diffusion in the gas phase, then

$$
G=\beta\left(C_{0}-C\right),
$$

where $G$ is an amount of bismuth, vaporized from the surface unit per time unit.

A bismuth shot contacts with the metal and then moves over the surface and is taken into the metal due to its circulation.

Equation (16) shows that in order to decrease the evaporation speed it is necessary to decrease the mass transfer coefficient $\beta$ and the difference of concentrations $\left(C_{0}-C\right)$. Here $C_{0}$ depends on the bismuth temperature, $C$ depends on the bismuth vapor concentration in the gas phase. If $C_{0}=C$, then evaporation speed becomes zero. In condition of the casting at atmospheric pressure, $C$ can not exceed the concentration corresponding to the atmospheric pressure. Fig. 3 shows a circulation of the metal in a central funnel.

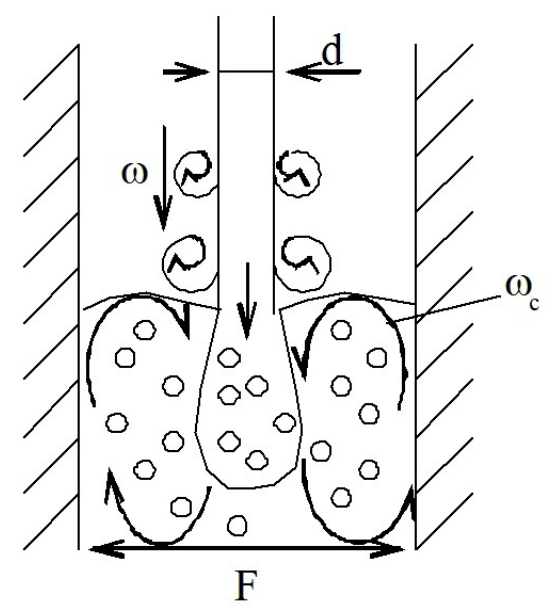

Fig. 3. The behavior of the metal in the central funnel: $d$ and $\omega$ are a diameter and a speed of metal jet; $\omega_{c}$ - is a circulation speed; $\mathrm{F}$ - is a surface of the riser

According to [6],

$$
\omega_{F}=0.414 \frac{\omega \cdot d}{F}, \beta=\frac{0.0178 \cdot \omega \cdot d}{R e^{0.2} F}, R e=\frac{\omega_{F} \cdot d_{B i}}{\nu},
$$

where $d_{B i}$ is a diameter of bismuth particle; $\nu$ is a kinematic viscosity of the gas.

$$
\beta \sim \omega^{0.8} d^{0.8}[8]
$$

Thus, the speed of bismuth evaporation depends on the stream flow speed and its diameter. The stream flow speed is reduced during the casting. The stream diameter is changed due to the half-open or close of a stopper. The stream flow speed can be reduced by steel casting through the tundish or other devices.

Steel casting by siphon is accompanied by severe turbulence, when either the stream flows from a ladle or the stream flows on a siphon wiring. Reynolds criterion can vary 
widely, when a ingot body and profitable part are filled. Consider the ingot casting under real conditions. Suppose that a diameter of the riser is $80 \mathrm{~mm}$. Then, in such riser, Reynolds criterion is $11.5 \times 105-3 \times 105$ during a filling of the ingot body and $0.45 \times 105-1 \times 105$ during a filling of profitable part [6]. Now suppose that a diameter of siphon wiring is $50 \mathrm{~mm}$. Then, in such siphon wiring, Reynolds criterion is $0.6 \times 105-1.2 \times 105$ during a filling of the ingot body and $0.18 \times 105-0.44 \times 105$ during a filling of profitable part. For metal stream contacting with the ingot, Reynolds criterion is equal to Reynolds criterion of siphon wiring up to a certain distance. During subsequent flow of the jet, Reynolds criterion decreases. Note the following conditions: last-mentioned values of Reynolds criterion, a roughness of the refractory wiring, sharp turns of stream at an angle of $90^{\circ}$. Therefore cavitation regions are formed. The regions may slam at certain moments. The pressure of about 1000 - 2000 atm. occurs in places where the cavitation regions slam.

Suppose that a steel includes elements with high vapor tension. Such elements boil at temperature of liquid steel, so cavitation regions are formed. The formation of cavitation regions is facilitated by nonmetallic inclusions of the steel $[5,7]$. The obtained cavitation regions are filled with bismuth vapor. In the zone with high pressure, the cavitation regions slam in steel volume or on surface of solidified steel crust. Therefore the crust is broken. In other cases, the liquid flow with cavitation regions may be in contact with the atmosphere. Then the cavitation regions open and the vapor moves from the regions to the atmosphere. Thus, we can eliminate both the loss of alloying elements and formation of surface defects of castings by adjusting the cavitation process. Note that dissolution of some alloying elements increase with increase of the pressure. So also we can local increase pressure to increase and accelerate the dissolution of such alloying elements. In this case, a liquid bismuth pellets are fragmented, because both the cavitation regions quickly slam and the pressure is high.

The tendency of liquid to be cavity is determined by the dimensionless criterion (a cavitation number):

$$
Q=\frac{p_{o}-p_{s t}}{\frac{\rho v^{2}}{2}}
$$

where $p_{o}$ is an absolute pressure; $v$ is a flow speed; $s t$ is a tension of saturated liquid vapor; $\rho$ is a density of the liquid.

According to A.D. Pernik [9], the number of cavitation is associated with Reynolds criterion:

$$
Q \approx R 5^{0.282}
$$

Without taking into account a surface tension, the absolute pressure and Reynolds criterion (Re) are founded by formulas (17) and (11):

$$
p_{o}=p_{a}+\rho g h
$$

where $p_{a}$ is an atmospheric pressure, $N / \mathrm{m}^{2} ; h$ is a height of metal column, $\mathrm{m}$.

Formula (17) shows that the main parameters, which influence on the process of cavitation development, are a flow speed, a saturated vapor pressure and an external pressure. The process of cavitation develops, when the speed and the tension of saturated vapor increase and the external pressure decreases.

Transform equation (17) and calculate the critical flow speed

$$
v=\left[\frac{\left(p_{a}+\rho_{A B} g h-p_{s t}\right) \cdot 2 \cdot \nu^{0.282}}{\rho_{B i} \cdot l^{0.282}}\right]^{1 / 0.282} .
$$


Fig. 4 shows its decision for $p_{a}=1 \mathrm{~atm}, h=0 ; \nu_{\text {steel }}=3.57 \times 10-7 \mathrm{~m}^{2} / \mathrm{s} ; \rho_{B i}=$ $9750 \mathrm{~kg} / \mathrm{m}^{3}, l=0.0005--0.0025 \mathrm{~m}$ and $\mathrm{h}=0$. Also, Fig. 4 shows that the critical speed is sharp reduced, when $p_{s t}$ is more than $93000 \mathrm{~N} / \mathrm{m}^{2}$. Now we take into account a height. Thus, the critical speed increases in $1.5-2.5$ times, when $h$ increases from 0 to $0.5 \mathrm{~m}$.

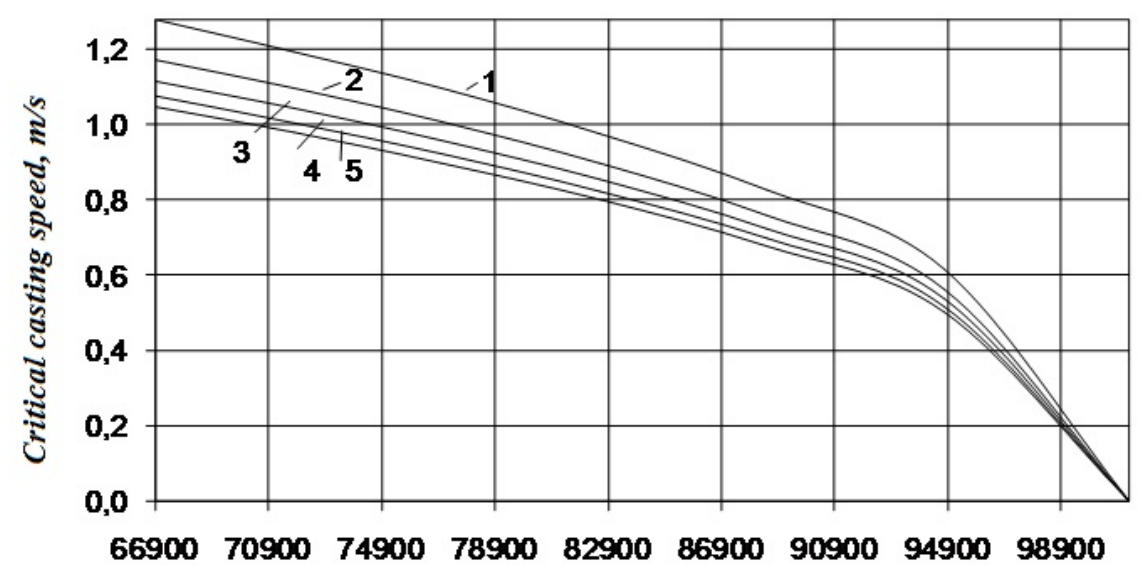

Saturated bismuth vapor presure, $\mathrm{N} / \mathrm{m}^{2}$

Fig. 4. The dependence of the critical casting speed on both a saturated bismuth vapor pressure and a particle size. We consider the following cases of particle diameter: $1-0.5 \mathrm{~mm} ; 2-1 \mathrm{~mm}$; $3-1.5 \mathrm{~mm} ; 4-2 \mathrm{~mm} ; 5-2.5 \mathrm{~mm}$

Consider a siphon casting of steel into ingots weighing 2.8 tons. Then a steel flow speed in the riser is $0.68-1.4 \mathrm{~m} / \mathrm{s}$ and $0.2-0.5 \mathrm{~m} / \mathrm{s}$ for filling of the ingot body and head, respectively. Also, a steel flow speed in the wiring siphon is $0.68-1.4 \mathrm{~m} / \mathrm{s}$ and $0.2-0.5$ $\mathrm{m} / \mathrm{s}$ for filling of the ingot body and head, respectively. The speed of metal stream, flowing from a ladle, up to its contact with a metal level in the riser is $11.9 \mathrm{~m} / \mathrm{s}$ at the beginning of steel casting and $4 \mathrm{~m} / \mathrm{s}$ at the end of the casting. Thus, an extensive cavitation zone occurs in place of the connection of metal stream with a melt during entire casting process. The size of such zone increases, when both the stream speed and its second flow expenditure increase [6]. The processes of cavitation in the siphon wiring and ingot bottom fade during the filling of both the ingot body and head, because their steel height (a static pressure) increases.

\section{Conclusion}

Thus, to increase the bismuth assimilation in the steel during a siphon casting it is necessary to implement such parameters of both casting and filling of bismuth, that involve the following. First, bismuth evaporation and evacuation of its vapor to the atmosphere are minimized. Second, the bismuth dissolving ends, when a bismuth particle moves in siphon wiring channels. Linear steel casting speed is maintained in the range of $10-15$ $\mathrm{mm} / \mathrm{s}$ in the mold up to height of $300-400 \mathrm{~mm}$. Then the speed is reduced to $5-7 \mathrm{~mm} / \mathrm{s}$ and the bismuth is input. After the end of bismuth input, the linear casting speed is increased up to $10-15 \mathrm{~mm} / \mathrm{s}$ during $2-5$ seconds. Casting end is performed with speed of $1.5-3 \mathrm{~mm} / \mathrm{s}$. 


\section{References}

1. Golubtsov V.A. [Theory and Practice of Introducing Additives into the Steel Outside the Furnace]. Chelyabinsk: Chelyabinsk State University, 2006, 403 p. (in Russian)

2. Kazantsev E.I. [Industrial Furnaces: Guide to Calculate and Design]. Moscow, Metallurgiya, 1975, 368 p. (in Russian)

3. Polyvyanny I.R., Ablanov A.D., Batyrbekova S.A. [Bismuth]. Alma-Ata, Nauka, 1989, 316 p. (in Russian)

4. Kutateladze S.S. [Heat and Hydrodynamic Resistance. Supplemental Benefit]. Moscow, Energoatomisdat, 1990, 365 p. (in Russian)

5. Krivandin V.A., Markov B.L. [Metallurgical Furnace]. Moscow, Metallurgiya, 1967, 672 p. (in Russian)

6. Efimov V.A. [Casting and Crystallization of Steel]. Moscow, Metallurgiya, 1976, 552 p. (in Russian)

7. Grigoryan V.A., Stomakhin A.Y., Panomarenko A.G. etc. [Physico-Chemical Calculations of EAF Processes: Proc. manual for schools]. Moscow, Metallurgiya Publ., 1989, 288 p. (in Russian)

8. Manohin A.I. [To Get Homogeneous Steel]. Moscow, Metallurgiya, 1978, 224 p. (in Russian)

9. Pernik A.D. [Cavitation Problems]. Leningrad, Sudostroenie, 1963, 355 p. (in Russian)

Andrey V. Ryabov, Under Graduate, Chelyabinsk; Associate Professor, PhD (Techn. Sci.), Department of Engineering and Technology of Production Materials, South Ural State University, (Zlatoust, Chelyabinsk region, Russian Federation), avrmetall@ya.ru

Received December 7, 2016

УДК 669.18.046:621.746

DOI: $10.14529 /$ jcem160403

\section{АНАЛИЗ ПОВЕДЕНИЯ ВИСМУТОВОЙ ДРОБИ ПРИ РАЗЛИВКЕ}

\section{А.В. Рябов}

В работе рассмотрен анализ поведения висмутовой дроби и предложены технологические рекомендации совершенствования процесса легирования при сифонной разливке стали в слитки массой 2.8 т. Для увеличения усвоения висмута в стали при сифонной разливке необходимо реализовать такие параметры разливки и подачи висмута, при которых испарение висмута и эвакуация его паров в атмосферу сводились бы до минимума, а растворение висмута закончилось при движении частицы висмута в каналах сифонной проводки. Линейная скорость разливки стали в изложнице до высоты 300 - 400 мм поддерживают в пределах 10 - 15 мм/с, после чего снижают до 5 7 мм/с и начинают ввод висмута. После окончания ввода висмута на $2-5$ сек линейную скорость разливки увеличивают до $10-15 \mathrm{~mm} / \mathrm{c}$. Окончание разливки проводят со скоростью $1.5-3 \mathrm{MM} / \mathrm{c}$.

Ключевые слова: легкообрабатываемая сталь; висмутовая дробъ; анализ; сталь; разливка стали. 


\section{Литература}

1. Голубцов, В.А. Теория и практика введения добавок в сталь вне печи / В.А. Голубцов. - Челябинск: ЧелГУ, 2006. - 403 с.

2. Казанцев, Е.И. Промышленные печи: справочное руководство для расчетов и проектирования / Е.И. Казанцев. - М.: Металлургия, 1975. - 368 с.

3. Полывянный, И.Р. Висмут / И.Р. Полывянный, А.Д. Абланов, С.А. Батырбекова. - Алма-Ата: Наука, 1989. - 316 с.

4. Кутателадзе, С.С. Теплопередача и гидродинамические сопротивления. Справочное пособие / С.С. Кутателадзе. - М.: Энергоатомиздат, 1990. - 365 с.

5. Кривандин, В.А. Металлургические печи / В.А. Кривандин, Б.Л. Марков. М.: Металлургия, 1967. - 672 с.

6. Ефимов, В.А. Разливка и кристаллизация стали / В.А. Ефимов. - М.: Металлургия, 1976. - 552 с.

7. Физико-химические расчеты электросталеплавильных процессов: Учеб. пособие для вузов / В.А. Григорян, А.Я. Стомахин, А.Г. Паномаренко и др. - М.: Металлургия, 1989. - 288 с.

8. Манохин, А.И. Получение однородной стали / А.И. Манохин. - М.: Металлургия, 1978. - $224 \mathrm{c}$.

9. Перник, А.Д. Проблемы кавитации / А.Д. Перник. - Л.: Судостроение, 1963. 355 c.

Рябов Андрей Валеръевич, магистрант, Челябинск; кандидат технических наук, дочент кафедры «Техника и технология производства материалов», ЮжноУральский государственный университет (г. Златоуст, Челябинская область, Российская Федерачия) avrmetall@ya.ru

Поступила в редакиию 7 декабря 2016 г. 